See discussions, stats, and author profiles for this publication at: https://www.researchgate.net/publication/318473239

\title{
Palaeo leaf economics reveal a shift in ecosystem function associated with the end-Triassic mass extinction event
}

Article in Nature Plants · July 2017

DOI: 10.1038/nplants.2017.104

CITATIONS

7

7 authors, including:

Wuu Kuang Soh

University College Dublin

14 PUBLICATIONS 79 CITATIONS

SEE PROFILE

Margret Steinthorsdottir

Swedish Museum of Natural History

30 PUBLICATIONS 408 CITATIONS

SEE PROFILE
READS

428

(1) University of Leeds

15 PUBLICATIONS 167 CITATIONS

SEE PROFILE

Andrew C Parnell

Maynooth University

103 PUBLICATIONS 5,129 CITATIONS

SEE PROFILE

Some of the authors of this publication are also working on these related projects:

Project Mid-Cretaceous south polar forests View project

Project Response of pan-Arctic permafrost peatlands to rapid climate warming View project 


\title{
Palaeo leaf economics reveal a shift in ecosystem function associated with the end-Triassic mass extinction event
}

\author{
W. K. Soh ${ }^{1 \star}$, I. J. Wright ${ }^{2}$, K. L. Bacon ${ }^{3}$, T. I. Lenz ${ }^{2}$, M. Steinthorsdottir ${ }^{4,5}$, A. C. Parnell ${ }^{6}$ \\ and J. C. McElwain'
}

${ }^{1}$ School of Biology and Environmental Science, Earth Institute, University College Dublin, Belfield, Dublin 4, Ireland. ${ }^{2}$ Department of Biological Sciences, Macquarie University, Sydney, New South Wales 2109, Australia. ${ }^{3}$ School of Geography, University of Leeds, Leeds LS2 9JT, UK. ${ }^{4}$ Department of Geological Sciences and Bolin Centre for Climate Research, Stockholm University, SE 10961 Stockholm, Sweden. ${ }^{5}$ Department of Paleobiology, Swedish Museum of Natural History, SE-104 05 Stockholm, Sweden. ${ }^{6}$ School of Mathematics \& Statistics, Insight Centre for Data Analytics, University College Dublin, Belfield, Dublin, Ireland. *e-mail: wuu.soh@ucd.ie 


\section{Supplementary Information Text}

\section{Paleo-LMA proxy development}

LMA-cuticle thickness relationship. High leaf mass per area leaves are thought to have longer lifespans (slower tissue turnover) because of their higher leaf engineering strength and coordination with other leaf economic traits such as defence chemistry ${ }^{1,2}$. Slow tissue turnover in combination with low nutrient concentrations in both green and senesced leaves are key adaptations by which species can be evolutionarily and ecologically competitive on low nutrient soils ${ }^{3}$. However, the low photosynthetic rates, slow growth and limited ability to respond to changing light environments (from neighbouring vegetation) tends to preclude such species from high nutrient situations where instead low LMA species dominate. Therefore, being able to reliably estimate the LMA of fossil plant taxon provide considerable insight into their ecological and physiological strategies and, more broadly, into the communities in which they lived.

LMA cannot be measured directly on fossil plant material. At present, there are only two methods of estimating paleo-LMA from fossils: via leaf petiole and area dimensions ${ }^{4}$, and via adaxial epidermal cell density ${ }^{5}$. The first method is based on a strong scaling relationship between leaf petiole width-blade area and leaf mass ${ }^{4}$ but is unavoidably limited in its application to well-preserved whole leaves, with undamaged petioles. The second method relies on a positive relationship between LMA and adaxial epidermal cell density ${ }^{5}$, however the approach has only been tested within Ginkgoales. Here we present a third, complementary approach, with potential for broad utility, based on a simple and tight scaling relationship between leaf cuticle thickness and LMA (Fig. S8). The link between LMA and leaf cuticle thickness per area for laminas with flat or distinct abaxial and adaxial surfaces can be described by the following equation:

LMA $=$ Density $\times$ lamina thickness

Eqn. 1

The above equation can be expanded into the following:

$\mathrm{LMA}=(\mathrm{D} 1 \times \mathrm{CT})+(\mathrm{D} 2 \times \mathrm{TT}) \quad$ Eqn. 2

Where D1 = leaf cuticle density, D2 = leaf tissue density, $\mathrm{CT}=$ cuticle thickness and TT $=$ tissue thickness - LMA is predominantly affected by these four components. However, the density of leaf cuticle thickness is approximately unity with a very narrow range between $0.96-1.24 \mathrm{gcm}^{-36,7}$ in woody plants, therefore cuticle thickness is more influential than density in determining variation in LMA in eqn. 2. Cuticle and tissue thickness both show a power law relationship with LMA on untransformed axes and when the variables were log-transformed we can conveniently regress LMA with cuticle and tissue thickness, giving three possible models (Table S9). The addition of tissue thickness (model 2 and 3) to LMAcuticle thickness model (model 1) did not substantially increase the adjusted $\mathrm{R}^{2}$ value or AIC (Table S9): models with cuticle and tissue thickness only increase variance explained by at most three percent from model 1. Based on the foregoing mechanistic and empirical evidence, we suggest that the LMA-cuticle thickness relationship proposed here (model 1) can be used as calibration for a new paleoLMA proxy.

Model diagnostics in the form of Q-Q plot and plot of residuals vs. fitted values were used to assess the fit of model 1 (Fig. S8). These diagnostic plots do not suggest a significant departure from linearity and heteroscedasticity of variance (Fig. S8b-c). Two potential influential points were identified by Cook's Distance analysis at the cut-off point 0.1 (Fig. S8d): Agathis lanceolata (sample no: 11-157a) and Ginkgo biloba (sample no: 11-84a). We re-fitted the model by removing the two influential points sequentially (Table S10). All model parameters, with or without influential points, were substantively close and consequently differences in their predictive power in paleo-LMA application was relatively small. We therefore retained all the 57 data points and applied the equation ' $\log _{10} \mathrm{LMA}=1.744+0.601 \log _{10} \mathrm{CT}$ ' in model 1 for estimating the LMA of fossil leaves.

Under the paleo-LMA framework, the training samples cover a broad range of flat-leaved gymnosperm taxa and therefore exclude cylindrical-leaved taxa from Pinaceae and Ephedraceae. Additionally, Gnetaceae and Welwitschiaceae were excluded since we could not easily obtain fresh material and the fossil record of Gnetaceae and Welwitschia cuticle is poor compared with that of conifers. To test for the influence of taxonomic structure in our dataset we also evaluated the cuticle thickness-LMA relationship using phylogenetic independent contrasts ${ }^{8}$ (PIC). For that analysis a phylogenetic tree was assembled for our 20 species included in this study using the online Phylomatic program ${ }^{9}$, based on a published consensus phylogeny, APG III ${ }^{10}$ (Fig. S2a). Subsequently, well-identified nodes were dated based on published ages from $L F Y$ and $N L Y$ single-copy nuclear genes ${ }^{11}$ and implemented in the tree using bladj module in Phylocom 4.2 $2^{12}$. The phylogenetic tree together with species-averaged LMA and cuticle thickness data were used to calculate trait contrasts in $\mathrm{R}$ package ape. The contrasts were adequately standardized as the plots of absolute and standard deviation of contrasts for each set of traits show no significant negative correlation (cuticle $\mathrm{R}^{2}=0.10, p$-value $>0.05$; LMA R $^{2}=0.10, p$-value $>0.05$, plots not shown). Following this, species-averaged cuticle thickness-LMA traits correlation were compared with the trait contrast correlation.. We found that both correlations maintained approximately the same magnitude and significant positive relationship before and after PIC (trait $\mathrm{n}=19$, $\mathrm{R}^{2}=0.86, p$-value $<0.001$; trait contrast $\mathrm{n}=20, \mathrm{R}^{2}=0.84, p$-value $<0.001$; Fig. S2b-c). This suggests that the cuticle thickness-LMA relationship within gymnosperms does not reflect any dependence on phylogenetic history, which further supports a mechanistic interpretation of the paleo-LMA framework. Our results, therefore, support the application of the paleo-LMA proxy on extinct Tr-J gymnosperm taxa such as Bennettitales that are not represented in the training data.

Cuticle thickness measurements. Plant cuticle consists primarily of insoluble cutin, cutan and soluble waxes, is highly resistant to physical and chemical changes ${ }^{13}$ and it is often preserved in fossilised 
material in the form of coalified compressions or as fragments in the rock matrix. The fossil cuticles in the current study show excellent preservation of nanoscale laminate structure within the cuticle proper. This, and the consistent levels of autofluorescence across all measured cuticle samples, suggested that the cuticles were not compressed significantly or differentially preserved between beds, despite clear evidence for mesophyll compression. Other cellular structures including cell walls were not clearly present in the fossil leaf cross sections but were represented by a coalified layer. We measured cuticle membranes (i.e. not including epidermal cell wall) in both the modern and fossil samples.

Adaxial cuticle is usually thicker than abaxial cuticle, and the difference between both sides ranges from $1 \%$ to $195 \%$ in extant samples. In the fossil leaf sections, the vertical segments in the 'mesophyll' layer (e.g. Fig. 1e) are chattering effects of microtoming. Fossil cuticle thickness is variable within a crosssection in comparison to modern gymnosperm samples because cuticles sometimes folds onto itself or becomes compressed during the fossilisation process. To overcome discrepancy in measurements, only cuticles with approximately even thickness across the length of fossil leaf samples were measured, and regions with extreme thickness were avoided. Cuticle thickness was measured ten times for each abaxial and adaxial side of each leaf using ImageJ, and the total 20 measurements averaged. Alternatively, ImageJ plugin (BoneJ $)^{14}$ can be used for determining mean cuticle thickness by measuring cuticle thickness at numerous intervals throughout the cuticle length with statistical and graphical outputs. This method however takes into account compressed and uncompressed sections. Both methods mentioned above produce almost similar results for comparison, we measured cuticle thickness on images Fig 1d-e in the main text using ImageJ with BoneJ plugin and compared the results with our primary method for measuring cuticle thickness (Table S11, Fig. S9).

Comparison of results based on the cuticle-LMA proxy with those based on petiole-LMA and cell-LMA proxies. Three calibrations are available for the petiole-LMA proxy, based on woody dicots ${ }^{4}$, extant gymnosperms ${ }^{15}$ (17 genera, 93 species), and on Ginkgo biloba ${ }^{5}$ only. The ginkgo- and gymnospermbased versions led to considerably higher estimates of LMA than those made with our cuticle-LMA proxy (Fig. S3b-c). There are several possible explanations for these discrepancies. Firstly, in the Ginkgo biloba training dataset ${ }^{5}$ the scaling relationship between LMA and petiole width (PW)-leaf blade area (A) is rather weak $\left(\log _{10} \mathrm{LMA}=0.285_{10} \mathrm{PW}^{2} / \mathrm{A}+2.882 ; \mathrm{R}^{2}=0.212, \mathrm{n}=36\right)$, leading to a correspondingly wide prediction interval (162.53 $\mathrm{gm}^{-2}, \mathrm{PI}_{95 \%}$ : $109.95,239.09)$. Secondly, the extant gymnosperm training dataset ${ }^{15}$ included taxa with widely-varying petiole length: the majority had short petioles or subsessile leaf ( $87 \%$, petiole $<5 \mathrm{~mm}$ long) while others Ginkgo and Gnetum are taxa with long petioles. Yet an assumption of the $\mathrm{PW}^{2} / \mathrm{A}$ approach is that there is little variation in petiole length ${ }^{4}$. In having a long and distinct petiole, Ginkgo leaves are physiognomically more similar to woody dicots than to most other gymnosperms. For this reason, we consider the petiole-LMA proxy based on woody dicots (667 woody dicot species-site pairs) as more suitable for inferring the LMA of our Tr-J Ginkgoales samples. The overestimation of LMA from woody dicot petiole-LMA proxy could be due to an underestimation of macrofossil leaf blade area caused by incomplete preservation. Leaf shrinkage effects on blade area can be ruled out because compression fossilization has been shown to have negligible effect on shrinkage ${ }^{16}$.

LMAs inferred from cuticle-LMA and epidermal cellLMA proxies from the same fossil sample showed an encouraging positive correlation $\left(\mathrm{LMA}_{\text {cuticle-LMA proxy }}=1.08 \mathrm{LMA}_{\text {epidermal cell-LMA }}\right.$ proxy, $\mathrm{R}^{2}=0.33, \mathrm{n}=44$ ) (Fig. $\mathrm{S} 3 \mathrm{~d}$ ). Similarly, a positive correlation between LMAs inferred from cuticle-LMA and petiole-LMA on the same fossil samples was evident, but this result should be treated with caution due to a small sample number $\left(\mathrm{LMA}_{\text {petiole-LMA proxy }}=59.5\right.$ $+0.24 \mathrm{LMA}_{\text {petiole-LMA proxy }}, \mathrm{R}^{2}=0.86, \mathrm{n}=5$ ).

\section{Outer- and inner-canopy leaf LMA variation in Tr-J} Bennettitales and Ginkgoales. Variation in LMA exists between species, among individuals of the same species and within individuals (among leaves) ${ }^{17,18}$. Within-individual variation largely results from differences in light exposure (outer- versus innercanopy leaves) and in leaf age ${ }^{17}$. In this paper, the possible bias in Bennettitales and Ginkgoales LMA due to differences in outer- and inner-canopy leaves is addressed separately on a per-taxon basis.

We reasoned that the large variation in LMA of Ginkagoales within and across fossil Beds most likely reflected differences among taxa that cannot be attributed, for example, to inadvertent systematic differences in sampling of outer- and inner-canopy leaves ('sun-leaf' and 'shade-leaf' respectively), for the following two reasons: (a) The leaf fossil record in tree species is believed to be strongly biased towards the preservation of outer canopy leaves ${ }^{19}$; and (b) the within-bed variation in Ginkgoales LMA is far too high to simply reflect differences among outer- and inner- canopy leaves. This is supported by the fact that the majority of Tr-J Ginkgoales LMA values within the same bed (Bed 1, 2, 7 and 8) are 48\%-152\% higher than the lowest value (mean $=94 \%$ ) which is considerably greater than the maximum range difference observed between extant Ginkgo biloba outer- and inner-canopy leaves $(c a .48 \%)^{20}$.

Bennettitales is an extinct gymnosperm order with no modern analog taxa with which to compare LMA variation of outerand inner-canopy leaves. Moreover, the fact that Bennettitales were most likely understory or subcanopy plants suggests that fossil leaf preservation may not be biased towards outer canopy leaves. We assessed the possible bias of outer- and inner-canopy leaves sampling in Bennettitales LMA with the following two methods:

Firstly, we grouped the cuticle type of bennettite samples into 'M1' and 'M2' leaf morphotype ${ }^{21}$ and compared their pooled LMA values. The 'M1' or 'M2' (Dataset 2) morphotypes likely represent 'sun' (outer-canopy) or 'shade' morphologies, respectively: the M1 leaf morphotype is defined by the presence of stomatal and epidermal papillae, and M2 by the presence of hair bases ${ }^{21}$. The mean LMA of M1 ('sun') leaf morphotype (62.77 gm-2, $\mathrm{PI}_{95 \%}: 52.45$, 74.99 ) is unlikely to be higher than the mean LMA of M2 ('shade') morphotype (66.20 gm-2 [PI $\left.{ }_{95 \%}: 56.63,76.68\right]$ ) (probability, $P(\mathrm{M} 1$ 
LMA $>$ M2 LMA $=0.25$ ) (Fig. S10a). Based on the study of fossil leaf morphotype, we suggest that morphological variation between outer- and inner-canopy leaves of Bennettitales is low.

Secondly, we examined the trend of phenotypic plasticity in Bennettitlates LMA across geologic time scales. We have captured a consistent proportion of the natural variation of Bennettitales LMA by quantifying the coefficient of variation (CV) in LMA on a bedby-bed basis. The range of Bennettitales $\mathrm{CV}$ on a bed-by-bed basis, which is between $0.23-0.26$ across Bed $1-5$ (Fig. S10b, Table S12), reflects the natural range of its LMA-phenotypic plasticity that would include the effect of outer- and inner-canopy leaf differences, i.e. difference due to light exposure. Next, we compared the trend in cumulative $\mathrm{CV}$ incrementally in fossil bed starting from Bed 1 to Bed 5 (Table S12). We observed that cumulative CV values calculated by incrementally pooling samples from Bed 1 to Bed 4 were within the Bennettitales LMA-phenotypic plasticity range (Fig. $\mathrm{S} 10 \mathrm{~b}$, Table S12). On the contrary, the cumulative CV inclusive of Bed 5 samples increased its value significantly beyond the typical plasticity range of $0.23-0.26$ ( $\mathrm{CV}$ for pooled Beds $1-5$ samples $=$ $0.34, \mathrm{PI}_{95 \%}: 0.26,0.45$ ) (probability, $P$ (Beds 1-5 CV $>$ Beds 1-4 $\mathrm{CV})=0.93)($ Table S12). Therefore, we suggest that the $55 \% \%$ surge in Bennettitales mean LMA from pre-warming (Beds 1-4) to peak warming (Beds 5-6) is larger than what could plausibly relate to differential sampling of outer- and inner-canopy leaves given that the cumulative coefficient of variation (CV) inclusive of Bed 5 exceeds the 'typical' range of Bennettitales LMA-phenotypic plasticity.

Based on these two conclusions from the analysis of Bennettitales leaf morphotype and LMA variation, we rule out the prominence of outer- and inner-canopy leaf effect on LMA trends.

\section{Environmental effects on LMA during the Triassic- Jurassic (Tr-J) transition.}

Poorter et al. ${ }^{17}$ showed that low temperature, high salinity, low water availability, soil nutrient stress and increased light intensity can all increase LMA. At Astartekløft, we can confidently rule out the role of low temperature, high salinity and drought as potential drivers of increasing Bennettittales LMA because geological evidence indicates intense global warming at the boundary 22 and there is no sedimentological or palaeoecological evidence for marine incursion or severe drying ${ }^{23,24}$. By contrast, increasing fern abundance and other hydrophilic floral elements suggest increasing water availability across the Tr-J, with peak water availability and swamp development coinciding with peak warmth ${ }^{24}$. It is more difficult to assess the likely influence of changes in palaeo-light intensity, however, as high LMA in Bed 5 coincides stratigraphically with peak volcanic activity in the Central Atlantic Magmatic Province $(\mathrm{CAMP})^{25}$, and as volcanism is associated with the generation of large quantities of volatiles and particulates, it is more likely that global dimming rather than brightening prevailed at and across the Tr-J boundary. Based on these arguments, the likelihood that high LMA was driven by a systematic trend of increasing light intensity is also diminished.

\section{Palaeoecological protocol and the absence of Ginkgoales specimens in plant beds.}

The absence of Ginkgoales specimens in certain plant beds is very meaningful because the entire palaeoecological dataset was amassed following strict sampling protocols in every bed (McElwain et al. ${ }^{24}$ ). The same amount of sediment was excavated for each bed. The palaeoecological protocol involved excavating the same volume of sediment from every bed (between $0.5 \mathrm{~m}^{3}$ to $1 \mathrm{~m}^{3}$ cubed per person per bed: four people excavating for every bed). The bed was also excavated at two to four lateral points along the bed to increase spatial sampling and the exact same amount of human effort was employed for each bed because a true palaeoecological protocol was followed an absence of fossil Ginkgoales specimens likely signifies a real paucity of Ginkgo in the palaeolandscape. The paleoecological pattern observed at one site in East Greenland is also reflected in presence/absence data across nine other sites across the whole Jameson Land, Greenland and museum collections from Scania, Sweden.

\section{Abundance-weighted community-mean LMA}

Mean LMA was calculated for each fossil bed by weighting the contribution of each morphogenus by its relative abundance, as follows:

Community-mean LMA $=\sum_{i}\left(\mathrm{LMA}_{i} \mathrm{x} \mathrm{RA}_{i}\right) / \sum \mathrm{RA}_{i}$

LMA $_{i}=$ LMA of the $i$ th morphogenera

$\mathrm{RA}_{i}=$ Relative abundance in the $i$ th morphogenus taken from McElwain et al ${ }^{24}$ (Table S13) 


\section{Supplementary Information Table}

Table S1. Comparison of mean LMA and 95\% prediction intervals $\left(\mathrm{PI}_{95 \%}\right)$ or 95\% confidence intervals $\left(\mathrm{CI}_{95 \%}\right)$ of extant Ginkgo biloba and Tr-J Bennettitales and Ginkgoales estimated by cuticle-LMA proxy in Fig. $2 \mathrm{~b}$.

\begin{tabular}{c|c|c|c|c} 
Taxa & Mean LMA $\left(\mathrm{gm}^{-2}\right)$ & Interval & Probability $(\boldsymbol{P})$ & - \\
\hline Bennettitales & 65.41 & $\mathrm{PI}_{95 \%}[56.76,74.97]$ & 51 & Sample number \\
\hline Tr-J Ginkgoales & 95.31 & $\mathrm{PI}_{95 \%}[86.03,105.2]$ & $\begin{array}{c}P(\text { Ginkgoales LMA }> \\
\text { Bennetitales LMA })=1\end{array}$ & 58 \\
\hline Extant Ginkgo biloba & 98.08 & $\mathrm{CI}_{95 \%}[95.62,100.59]$ & $\begin{array}{c}\text { P (Ginkgo biloba } \text { LMA }>\text { Tr-J } \\
\text { Ginkgoales LMA }>)=0.72\end{array} \quad 679$ \\
\hline
\end{tabular}

Table S2. Mean fossil cuticle thickness and mean fitted LMA of Bennettitales and Ginkgoales for total sample and bed-by-bed basis. In each cell from the top to bottom, values represent the order of mean cuticle thickness $(\mu \mathrm{m})$ with standard deviation, mean fitted LMA $\left(\mathrm{gm}^{-2}\right)$ with prediction interval in square bracket and sample size in bracket.

\begin{tabular}{|c|c|c|c|c|c|c|c|c|c|c|}
\hline & $\begin{array}{c}\text { Total } \\
\text { sample }\end{array}$ & Bed 1 & Bed 1.5 & Bed 2 & Bed 3 & Bed 4 & Bed 5 & Bed 6 & Bed 7 & Bed 8 \\
\hline Bennettitales & $\begin{array}{c}1.29 \pm 0.56 \\
65.41 \\
{[56.76} \\
74.97] \\
(51)\end{array}$ & $\begin{array}{c}1.04 \pm 0.1 \\
58.39 \\
{[45.15} \\
74.14] \\
(5)\end{array}$ & $\begin{array}{c}1.13 \pm 0.2 \\
61.28 \\
{[47.55} \\
78.23] \\
(5)\end{array}$ & $\begin{array}{c}1.01 \pm 0.21 \\
57.37 \\
{[47.27} \\
69.15] \\
(13)\end{array}$ & $\begin{array}{c}0.88 \pm 0.23 \\
52.60 \\
{[39.37} \\
69.30] \\
(4)\end{array}$ & $\begin{array}{c}1.18 \pm 0.20 \\
62.88 \\
{[52.53} \\
75.09] \\
(14)\end{array}$ & $\begin{array}{c}2.52 \pm 0.23 \\
99.81 \\
{[81.57} \\
120.11] \\
\text { (7) }\end{array}$ & $\begin{array}{c}1.35 \pm 0.95 \\
66.48 \\
{[45.28} \\
95.06] \\
(2)\end{array}$ & $\begin{array}{c}1.28 \\
66.40 \\
{[40.05} \\
103.80] \\
(1)\end{array}$ & - \\
\hline Ginkgoales & $\begin{array}{c}2.38 \pm 0.73 \\
95.31 \\
{[86.03} \\
105.20] \\
(58)\end{array}$ & $\begin{array}{c}1.78 \pm 0.80 \\
79.34 \\
{[62.62} \\
99.88] \\
(5)\end{array}$ & - & $\begin{array}{c}2.53 \pm 0.51 \\
99.10 \\
{[84.84} \\
115.24] \\
(13)\end{array}$ & $\begin{array}{c}1.52 \pm 0.16 \\
73.43 \\
{[59.34} \\
89.76] \\
(7)\end{array}$ & - & $\begin{array}{c}1.94 \\
85.83 \\
{[52.01} \\
134.54] \\
(1)\end{array}$ & $\begin{array}{c}1.69 \\
78.22 \\
{[47.08} \\
121.33] \\
(1)\end{array}$ & $\begin{array}{c}2.63 \pm 0.79 \\
101.23 \\
{[88.51} \\
115.66] \\
(19)\end{array}$ & $\begin{array}{c}2.67 \pm 0.51 \\
102.86 \\
{[88.05} \\
120.60] \\
(12)\end{array}$ \\
\hline
\end{tabular}

Table S3. Bennettitales mean LMA by Beds and 95\% prediction intervals $\left(\mathrm{PI}_{95 \%}\right)$ in Fig. $2 \mathrm{c}$.

\begin{tabular}{|c|c|c|c|c|}
\hline Plant Bed & Mean LMA $\left(\mathrm{gm}^{-2}\right)$ & $\mathbf{P I}_{95 \%}$ & Probability $(P)$ & Sample number \\
\hline $\begin{array}{c}\text { Beds 1-4 } \\
\text { (pre-warming) }\end{array}$ & 59.42 & {$[50.96,69.26]$} & - & 41 \\
\hline $\begin{array}{c}\text { Beds 5-6 } \\
\text { (peak warming) }\end{array}$ & 92.22 & {$[77.03,109.85]$} & $P($ Beds $5-6>$ Beds $1-4)=1$ & 9 \\
\hline $\begin{array}{c}\text { Beds } 7 \\
\text { (post-warming) }\end{array}$ & 66.5 & {$[40.42,103.38]$} & $\begin{array}{c}P(\text { Beds } 7>\text { Beds } 5-6)=0.08 \\
P(\text { Bed } 7>\text { Beds } 1-4)=0.64\end{array}$ & 1 \\
\hline
\end{tabular}

Table S4. Ginkgoales mean LMA by Beds and 95\% prediction intervals $\left(\mathrm{PI}_{95^{\circ}}\right)$ in Fig. 2 d.

\begin{tabular}{|c|c|c|c|c|}
\hline Plant Bed & Mean LMA $\left(\mathrm{gm}^{-2}\right)$ & $\mathbf{P I}_{95 \%}$ & Probability $(P)$ & Sample number \\
\hline $\begin{array}{c}\text { Beds 1-4 } \\
\text { (pre-warming) }\end{array}$ & 87.97 & {$[77.37,99.93]$} & $P($ Beds $1-4>$ Beds 5-6) $=0.69$ & 25 \\
\hline $\begin{array}{c}\text { Beds 5-6 } \\
\text { (peak warming) }\end{array}$ & 81.62 & {$[55.9,115.82]$} & $P($ Beds $5-6>$ Beds $1-4)=0.3$ & 2 \\
\hline $\begin{array}{c}\text { Beds 7-8 } \\
\text { (post-warming) }\end{array}$ & 101.76 & {$[90.86,114.16]$} & $\begin{array}{l}P(\text { Beds } 7-8>\text { Beds } 5-6)=0.91 \\
P(\text { Beds } 7-8>\text { Beds } 1-4)=0.98\end{array}$ & 31 \\
\hline
\end{tabular}


Table S5. Comparison of mean LMA and 95\% prediction intervals $\left(\mathrm{PI}_{95 \%}\right)$ or 95\% confidence intervals $\left(\mathrm{CI}_{95 \%}\right)$ of extant Ginkgo biloba, and Tr-J Ginkgoales estimated by cuticle-LMA, petiole-LMA and epidermal-LMA proxies in Fig. 2e.

\begin{tabular}{|c|c|c|c|}
\hline Source of LMA & Mean LMA $\left(\mathrm{gm}^{-2}\right)$ & Interval & Probability $(P)$ \\
\hline Extant Ginkgo biloba & 98.08 & $\mathrm{CI}_{95 \%}[95.62,100.59]$ & $P($ Ginkgo biloba LMA $>$ Cuticle-LMA proxy $)=0.72$ \\
\hline Cuticle-LMA proxy & 95.31 & $\mathrm{PI}_{95 \%}[86.03,105.2]$ & $P($ Cuticle-LMA proxy $>$ Extant Ginkgo biloba $)=0.51$ \\
\hline Cell-LMA proxy & 104.46 & $\mathrm{PI}_{95 \%}[95.97,113.78]$ & $P($ Cell-LMA proxy $>$ Cuticle-LMA proxy $)=0.91$ \\
\hline $\begin{array}{l}\text { Petiole-LMA proxy } \\
\text { (woody dicot) }\end{array}$ & 131.79 & $\mathrm{PI}_{95 \%}[122.08,142.27]$ & $P($ Petiole-LMA proxy woody dicot $>$ Cell-LMA proxy $)=1$ \\
\hline $\begin{array}{l}\text { Petiole-LMA proxy } \\
\quad(\text { Ginkgo biloba })\end{array}$ & 162.53 & $\mathrm{PI}_{95 \%}[109.95,239.09]$ & $\begin{array}{c}P(\text { Petiole-LMA proxy G. biloba }>\text { Cuticle-LMA proxy })=0.99 \\
P(\text { Petiole-LMA proxy G. biloba }>\text { Cell-LMA proxy })=0.98\end{array}$ \\
\hline $\begin{array}{l}\text { Petiole-LMA proxy } \\
\text { (gymnosperm) }\end{array}$ & 196.10 & $\mathrm{PI}_{95 \%}[168.14,227.76]$ & $\begin{array}{c}P(\text { Petiole-LMA proxy gymnosperm }>\text { Petiole-LMA proxy Ginkgo } \\
\text { biloba })=0.85\end{array}$ \\
\hline
\end{tabular}

Table S6. Total (Bennettitales and Ginkgoales) mean LMA by Beds and 95\% prediction interval (PI $\left.{ }_{95 \%}\right)$ in Fig. $2 \mathrm{f}$

\begin{tabular}{c|c|c|c|c}
\hline Bed & Bed height & Mean LMA & PI $_{95 \%}$ & Sample number \\
\hline 1 & 13.58 & 68.93 & {$[57.04,82.63]$} & 10 \\
\hline 1.5 & 23.04 & 61.6 & {$[48.19,78.6]$} & 26 \\
\hline 2 & 33.88 & 78.25 & {$[68.05,89.7]$} & 11 \\
\hline 3 & 37.51 & 65.92 & {$[54.57,79.38]$} & 14 \\
\hline 4 & 40.97 & 62.98 & {$[52.71,74.83]$} & 8 \\
\hline 5 & 46.88 & 97.92 & {$[51.8,93.57]$} & 3 \\
\hline 7 & 60.86 & 70.32 & {$[86.98,113.51]$} & 20 \\
\hline
\end{tabular}

Table S7. Abundance-weighted community-mean LMA by warming period and 95\% prediction interval (PI $\left.{ }_{95 \%}\right)$ in Fig. 3d.

\begin{tabular}{|c|c|c|c|c|}
\hline Plant Bed & LMA & $\mathbf{P I}_{95 \%}$ & Probability $(P)$ & Sample number \\
\hline $\begin{array}{c}\text { Beds 1-4 } \\
\text { (pre-warming) }\end{array}$ & 61.57 & {$[53.19,71]$} & - & 66 \\
\hline $\begin{array}{c}\text { Beds 5-6 } \\
\text { (peak warming) }\end{array}$ & 83.87 & {$[69.75,100.32]$} & $\begin{array}{c}P \text { (Beds } 5-6>\text { Beds } 1-4) \\
=0.99\end{array}$ & 11 \\
\hline $\begin{array}{c}\text { Beds 7-8 } \\
\text { (post-warming) }\end{array}$ & 101.74 & {$[90.46,114.25]$} & $\begin{array}{c}P(\text { Beds } 7-8>\text { Beds } 5-6) \\
=0.98\end{array}$ & 32 \\
\hline
\end{tabular}

Table S8. Abundance-weighted community-mean LMA by Beds and 95\% prediction interval ( $\mathrm{PI}_{95 \%}$ ) in Fig. S6.

\begin{tabular}{c|c|c|c|c}
\hline Bed & Bed height & Mean LMA $\left(\mathrm{gm}^{-2}\right)$ & PI $_{95 \%}$ & Sample number \\
\hline 1 & 13.58 & 58.89 & {$[45.63,76.45]$} & 10 \\
\hline 1.5 & 23.04 & 58.76 & {$[44.16,76.4]$} & 26 \\
\hline 2 & 33.88 & 79.73 & {$[69.21,91.71]$} & 11 \\
\hline 3 & 37.51 & 64.58 & {$[52.66,78.39]$} & 14 \\
\hline 4 & 40.97 & 62.78 & {$[82.07,75.28]$} & 8 \\
\hline 5 & 46.88 & 99.41 & {$[49.13,93.25]$} & 3 \\
\hline 6 & 60.86 & 68.24 & {$[88.25,114.66]$} & 20 \\
\hline
\end{tabular}


Table S9. Linear regression of LMA with cuticle thickness (CT) and tissue thickness (TT). ***p $\leq 0.001 ; * * \mathrm{p} \leq 0.01,{ }^{*} \mathrm{p} \leq 0.05,{ }^{\mathrm{ns}} \mathrm{p}>0.05$.

\begin{tabular}{|c|c|c|c|c|}
\hline Model $(n=57)$ & Adjusted $\mathbf{R}^{2}$ & F statistics & AIC & BIC \\
\hline (1) $\log _{10} \mathrm{LMA}=1.74 * * *+0.60 * * * \log _{10} \mathrm{CT}$ & 0.783 & $203.4^{* * *}(\mathrm{df}=1 ; 55)$ & -96.86 & -90.73 \\
\hline (2) $\log _{10} \mathrm{LMA}=1.15^{* *}+0.52 * * * \log _{10} \mathrm{CT}+0.24^{\mathrm{ns}} \log _{10} \mathrm{TT}$ & 0.789 & $105.7 * * *(\mathrm{df}=2 ; 54)$ & -97.44 & -89.27 \\
\hline (3) $\log _{10} \mathrm{LMA}=-0.92^{\mathrm{ns}}+2.98 * * \log _{10} \mathrm{CT}+1.06^{* *} \log _{10} \mathrm{TT}-0.96 * * \log _{10} \mathrm{TT} \cdot \log _{10} \mathrm{CT}$ & 0.813 & $82.4 * * *(\mathrm{df}=3 ; 53)$ & -103.56 & -93.35 \\
\hline
\end{tabular}

Table S10. Linear regression of LMA and cuticle thickness (model 1) with and without potential influential points. $* * * \mathrm{p} \leq 0.001 ; * * \mathrm{p} \leq 0.01, * \mathrm{p}$ $\leq 0.05,{ }^{\text {ns }} \mathrm{p}>0.05$.

\begin{tabular}{l|c|c|c|c|c}
\multicolumn{1}{c|}{ Model } & Slope & Intercept & Adjusted R & Residual standard error & \multicolumn{1}{c|}{ F statistics } \\
\hline Full dataset & $0.601 * * * \pm 0.042$ & $1.744 * * * \pm 0.030$ & 0.783 & $\begin{array}{c}203.4 * * * \\
(\mathrm{df}=1 ; 55)\end{array}$ \\
\hline Without sample $11-84 a$ & $0.578^{* * *} \pm 0.040$ & $1.764 * * * \pm 0.029$ & 0.787 & $0.093(\mathrm{df}=55)$ \\
\hline Without sample $11-84 a$ and $11-157 a$ & $0.595 * * * \pm 0.040$ & $1.757 * * * \pm 0.028$ & 0.801 & $0.091(\mathrm{df}=53)$ \\
$(\mathrm{df}=1 ; 54)$
\end{tabular}$\quad \begin{gathered}219.2 * * * \\
(\mathrm{df}=1 ; 53)\end{gathered}$

Table S11. Mean cuticle thickness comparison of values in dataset and values measured by ImageJ BoneJ plugin.

\begin{tabular}{l|c|c}
\multirow{2}{*}{ Fossil sample } & \multicolumn{2}{|c}{ Mean and standard deviation $(\mu \mathrm{m})$} \\
\cline { 2 - 3 } & $\begin{array}{c}\text { Averaged of 20 points including upper and lower surface } \\
\text { covering wider length of fossil section }\end{array}$ & ImageJ BoneJ plugin \\
\hline Fig 1D (sample ID 47200a) & $1.68 \pm 0.3$ & $1.82 \pm 0.32$ \\
\hline Fig 1E (sample ID 47103a) & $3.27 \pm 0.52$ & $3.63 \pm 0.97$ \\
\hline
\end{tabular}

Table S12. Bennettitales LMA cumulative coefficient of variation $(\mathrm{CV})$ and $95 \%$ prediction interval interval $\left(\mathrm{PI}_{95 \%}\right)$.

\begin{tabular}{c|c|c|c|c}
\hline Plant beds & Cumulative LMA CV & Interval & CV on bed-by-bed basis & Probability $(\boldsymbol{P})$ \\
\hline Bed 1 & 0.23 & {$[0.08,0.41]$} & 0.23 & - \\
\hline Beds 1-1.5 & 0.25 & {$[0.13,0.4]$} & 0.24 & $P($ Bed $1-1.5>$ Beds 1$)=0.58$ \\
\hline Beds 1-2 & 0.26 & {$[0.18,0.37]$} & 0.26 & $P($ Beds $1-2>$ Beds $1-1.5)=0.58$ \\
\hline Beds 1-3 & 0.26 & {$[0.19,0.36]$} & 0.26 & $P($ Beds $1-3>$ Beds $1-2)=0.54$ \\
\hline Beds 1-4 & 0.27 & {$[0.2,0.35]$} & 0.26 & $P($ Beds $1-4>$ Beds $1-3)=0.52$ \\
\hline Beds 1-5 & 0.34 & {$[0.26,0.45]$} & 0.23 & $P($ Beds $1-5>$ Beds $1-4)=0.93$ \\
\hline
\end{tabular}

Table S13. Relative abundance data from McElwain et al ${ }^{24}$.

\begin{tabular}{|l|c|c|c|c|c|c|c|c|c} 
Morphogenera/plant bed & Bed 1 & Bed 1.5 & Bed 2 & Bed 3 & Bed 4 & Bed 5 & Bed 6 & Bed 7 & Bed 8 \\
\hline Anomozamites & 16.07 & 32.26 & 8.14 & 0.19 & 27.05 & 0.10 & - & 0.46 & - \\
\hline Baiera & 6.25 & - & - & 1.33 & - & - & - & - \\
\hline Bennettitales & - & - & - & - & - & 1.71 & 3.91 & - \\
\hline Ginkgoites & 6.25 & - & 31.01 & - & 0.11 & - & 0.80 & 24.77 & - \\
\hline Pterophyllum & 25.00 & 4.84 & 18.99 & 2.10 & 50.23 & - & - & - \\
\hline Sphenobaiera & - & - & - & 1.14 & - & - & - & 20.95 & 34.39 \\
\hline
\end{tabular}




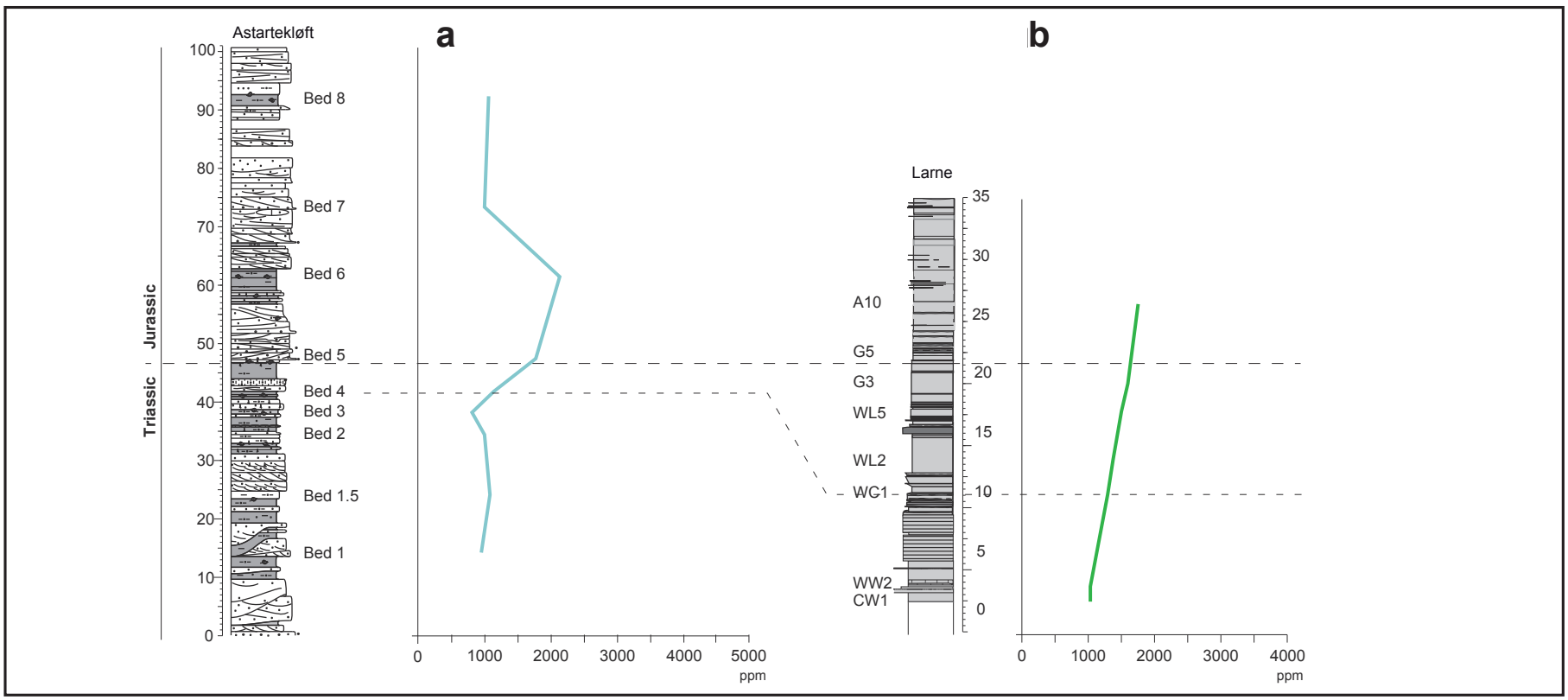

Fig. S1. Reconstruction of paleoatmospheric $\mathrm{CO}_{2}$ showing an increase in concentration across Triassic/Jurassic boundary inferred from fossil stomatal densities at two independent $\operatorname{sites}^{26}: \mathbf{a}$, Astartekløft, East Greenland and b, Larne, Northern Ireland.

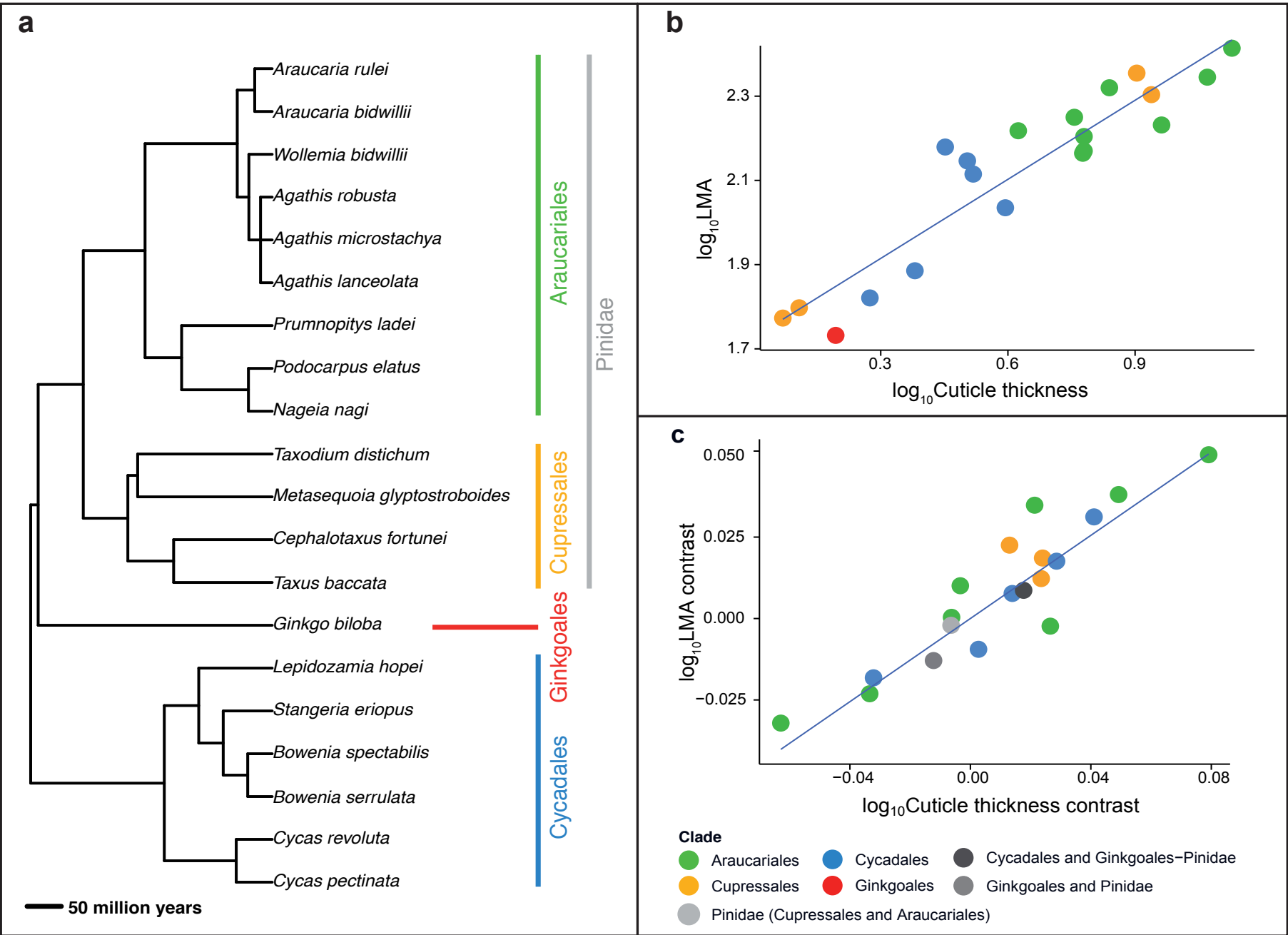

Fig S2. Phylogenetic independent contrasts analysis. a, Gymnosperm phylogenetic tree of sampled extant species based on APG III ${ }^{10}$ and divergence times based on $L F Y$ and $N L Y$ single-copy nuclear genes ${ }^{11}$. b. Scatter plot and regression line of species-averaged log scale cuticle thickness and LMA traits, showing a strong significant cuticle thickness-LMA relationship $\left(\mathrm{n}=20, \mathrm{R}^{2}=0.86, p\right.$-value $\left.=2.37 \mathrm{E}-09\right)$. $\mathrm{c}$, Scatter plot and regression line of species-averaged log-scale cuticle thickness and LMA contrast, showing a strong positive relationship after accounting for phylogenetic non-independence. $\left(\mathrm{n}=20, \mathrm{R}^{2}=0.84, p\right.$-value $\left.=9.43 \mathrm{E}-09\right)$. 

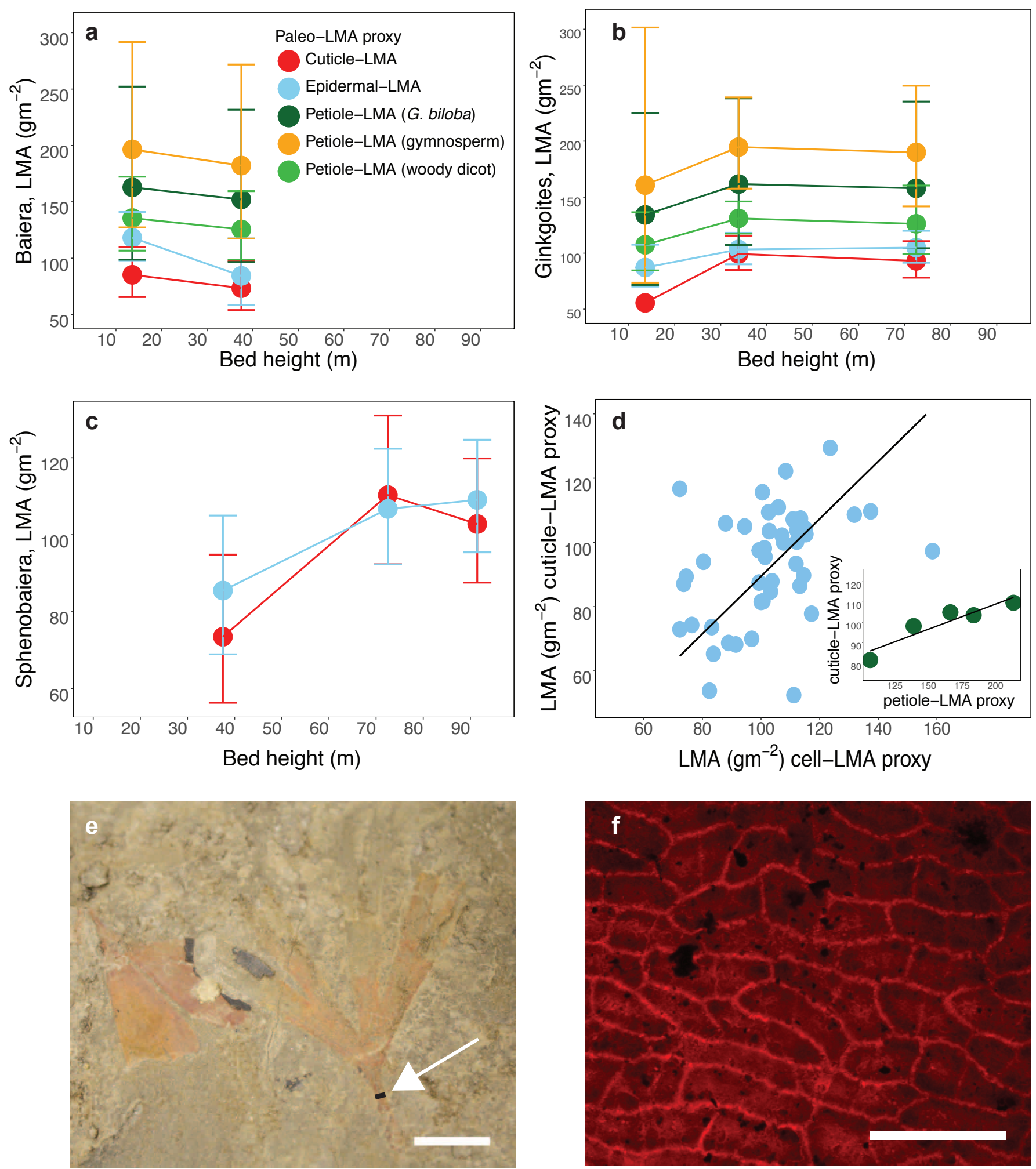

Fig. S3. Comparison of Tr-J Ginkgoales LMA inferred from three independent proxies based on cuticle thickness (cuticle-LMA), petiole widthblade area (petiole-LMA ${ }^{4,15}$ ) and adaxial epidermal cell density (epidermal cell-LMA ${ }^{5}$ ) among plant beds and samples. a, Dotplots showing Baiera mean LMA trend in Bed 1 and 3 among different proxies. b. Dotplots showing Ginkgoites mean LMA trend in Bed 1, 2 and 7 among different proxies. c, Dotplots showing Sphenobaiera LMA trend in Bed 3, 7 and 8 among different proxies. d, Scatterplot of LMAs from the same fossil cuticle samples inferred from cuticle-LMA and epidermal cell-LMA proxies, line is a regression through origin $\left(\mathrm{LMA}_{\text {cuticle-LMA proxy }}=1.08 * \mathrm{LMA}_{\text {epidermal cell-LMA proxy }}, \mathrm{R}^{2}=0.33, \mathrm{n}=44\right)$, inset shows LMAs from the same fossil cuticle samples inferred from cuticle-LMA and petiole cell-LMA proxy (woody dicot) $\left(\mathrm{LMA}_{\text {petiole-LMA proxy }}=59.5+0.24 * \mathrm{LMA}_{\text {petiole-LMA proxy }}, \mathrm{R}^{2}=0.86, \mathrm{n}=5\right)$. e, Example of macrofossil specimen used for petiole-LMA proxy, sample 46988, Ginkgoites, arrow indicates measured petiole width, white bar $=1 \mathrm{~cm}$. f, Example of fossil cuticle showing adaxial epidermal cells used for cell-LMA proxy, sample 46981, Baiera, bar $=100 \mu \mathrm{m}$. Dotplot whiskers are $95 \%$ prediction intervals. 


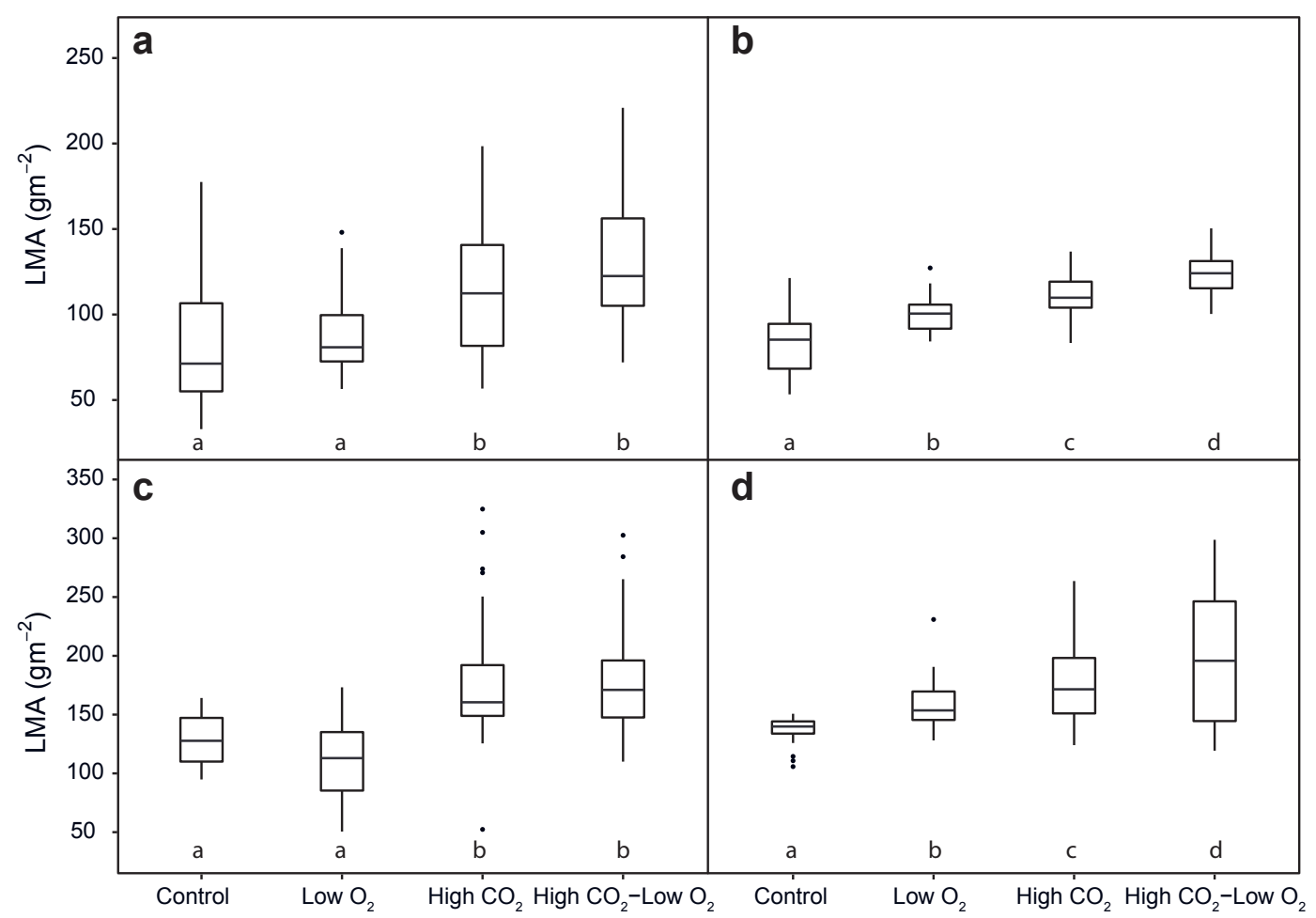

Fig. S4. Box plots showing LMA values for each species in each palaeoatmospheric treatment, dataset from Bacon et al. ${ }^{27}$. a, Ginkgo biloba. b, Dicksonia antartica. c, Lepidozamia hopei. d, Lepidozamia peroffskyana. Boxes represent the interquartile range (IQR), horizontal lines within the boxes represent medians, and whiskers extend to 1.5 times the IQR, black dots are outliers. Letters below boxplots indicate significant different groups by Wilcoxon rank-sum test $(p$-value $<0.05)$.

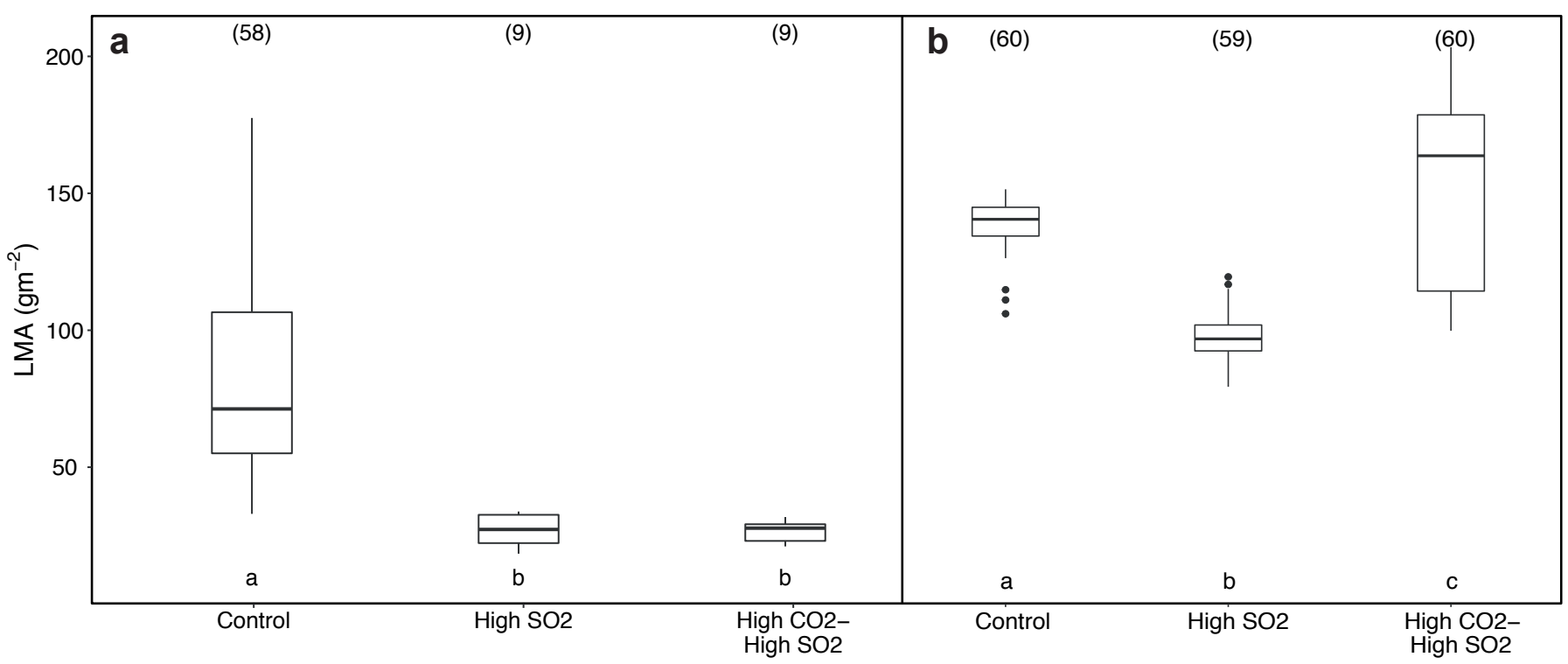

Fig. S5. Box plots showing LMA values for each species in each palaeoatmospheric treatment, dataset from Bacon et al. ${ }^{28}$. a, Ginkgo biloba. b, Lepidozamia peroffskyana. A full account of the experiment which will be published as a separate paper is in preparation. Boxes represent the interquartile range (IQR), horizontal lines within the boxes represent medians, and whiskers extend to 1.5 times the IQR, black dots are outliers. Letters below boxplots indicate significant different groups by Wilcoxon rank-sum test ( $p$-value $<0.05)$. Sample sizes are given in bracket. 


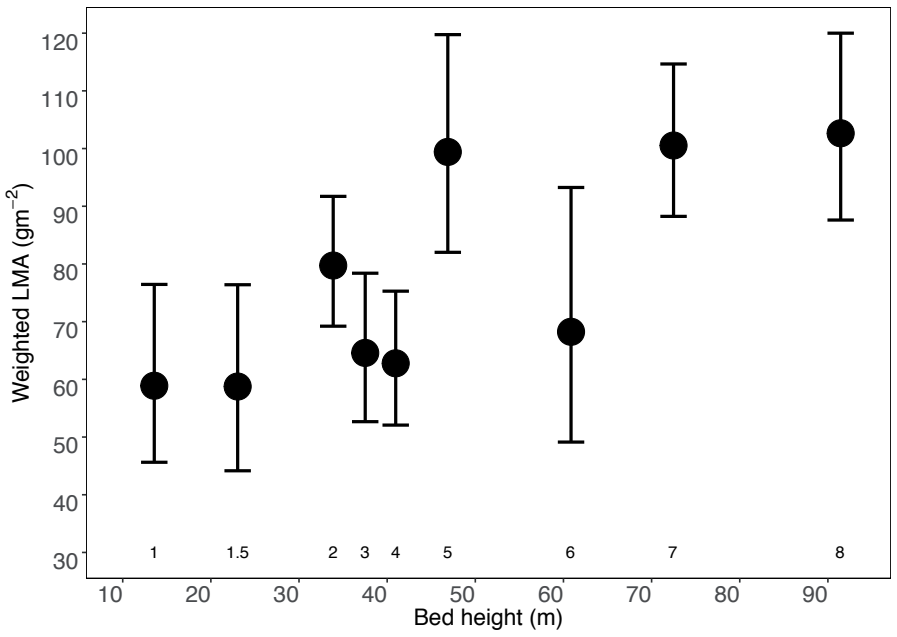

Fig. S6. Temporal trends in community-mean LMA by Beds for combined Ginkgoales and Bennettitales, with $95 \%$ prediction interval whiskers

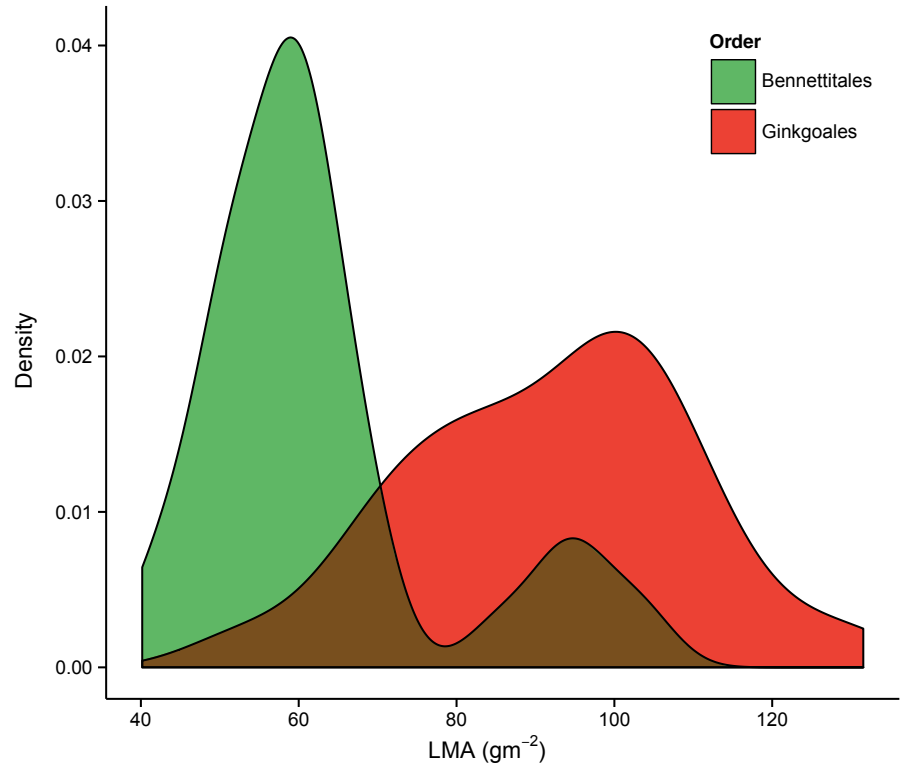

Fig. S7. Kernel density plot of leaf mass per area (LMA) in Bennettitales and Ginkgoales showing large overlap among the taxa within the same order-level compared to between orders.

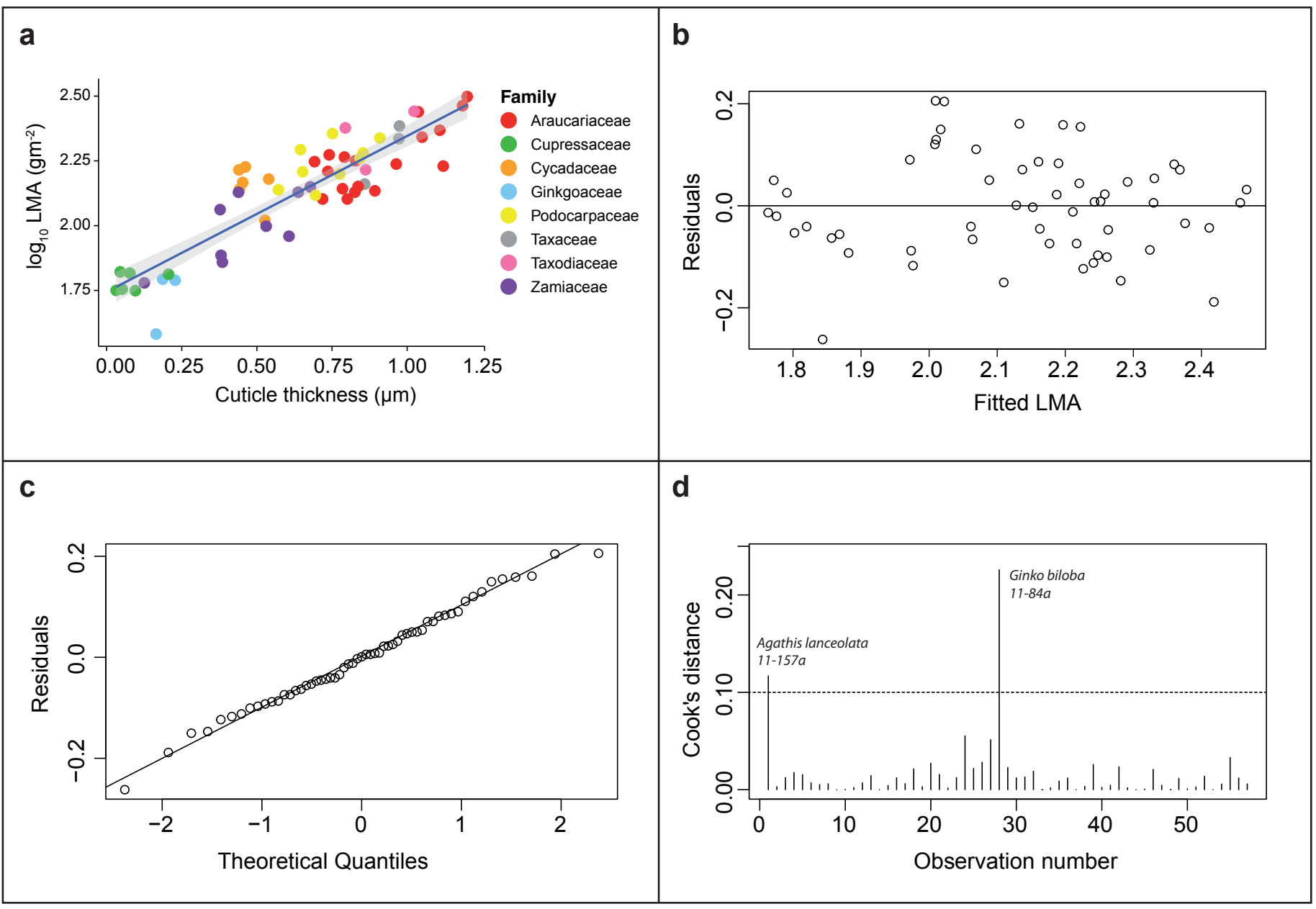

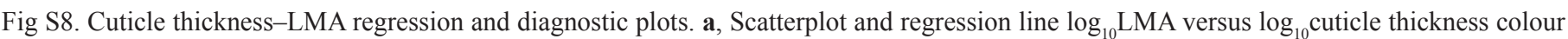
coded by family $\left(\log _{10} \mathrm{LMA}=0.601 \log _{10} \mathrm{CT}+1.744 ; \mathrm{R}^{2}=0.78, \mathrm{n}=57\right)$, shaded area is $95 \%$ confidence interval band. $\mathbf{b}$, Residual versus fitted LMA plot showing the residuals and the fitted values are uncorrelated, an indication of homoscedastic linear model. c, Q-Q plot showing a reasonably normally distributed residuals. d, Plot of Cook's distance values showing two potentially influential points with values $>0.1$ in sample Agathis lanceolata 11-157a and Ginkgo biloba 11-84a. 

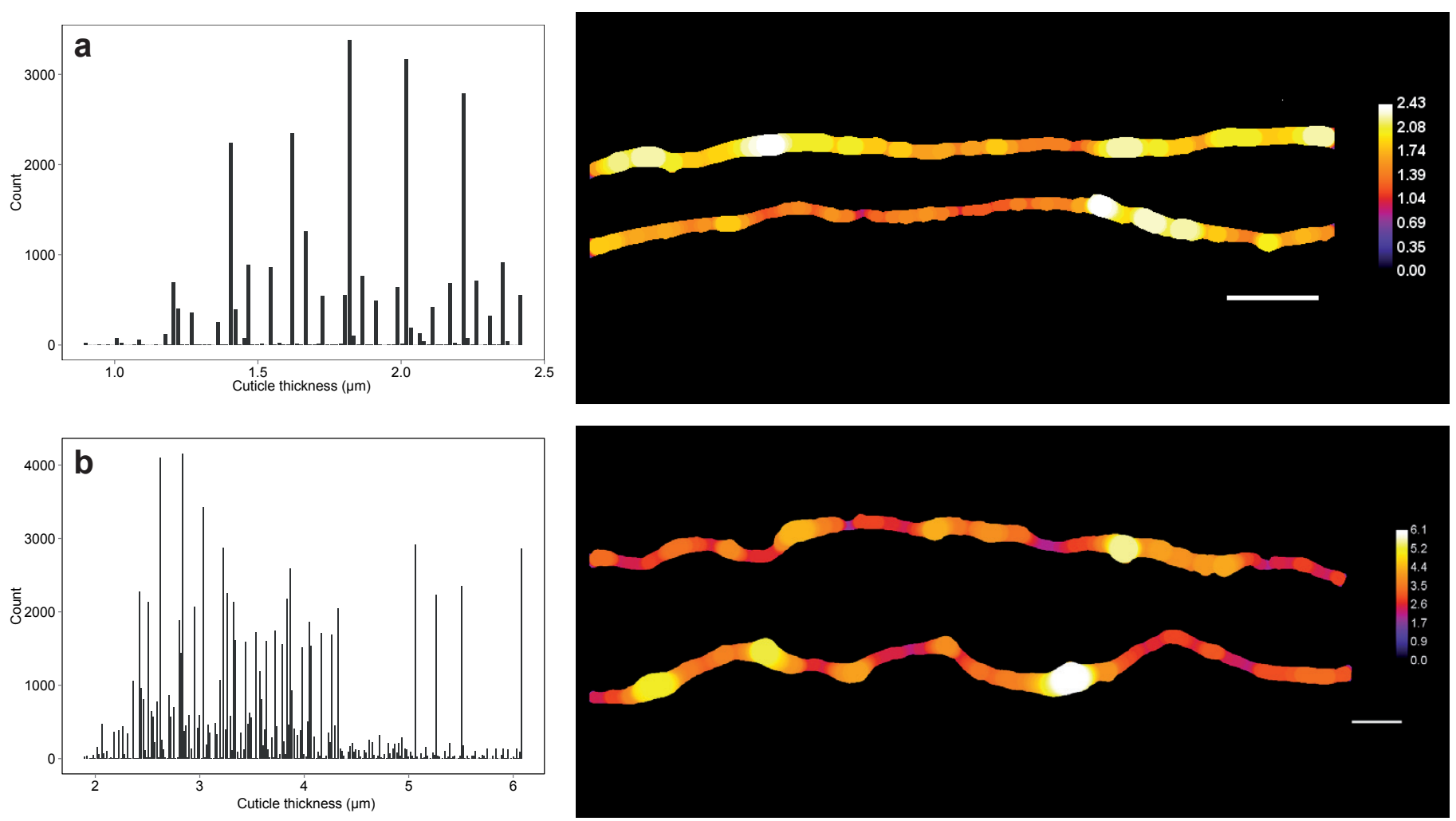

Fig. S9. ImageJ BoneJ plugin analysis showing histograms of count (y-axis) of cuticle thickness measurements (x-axis, bin 100) on fossil cuticle cross section. Adjacent figure shows measured fossil cuticle thickness in different thickness indicated by color code in micrometer scale. White horizontal scale bar $=10 \mu \mathrm{m}$. a, Fig 1D (sample ID 47200a). b, Fig 1E (sample ID 47103a).
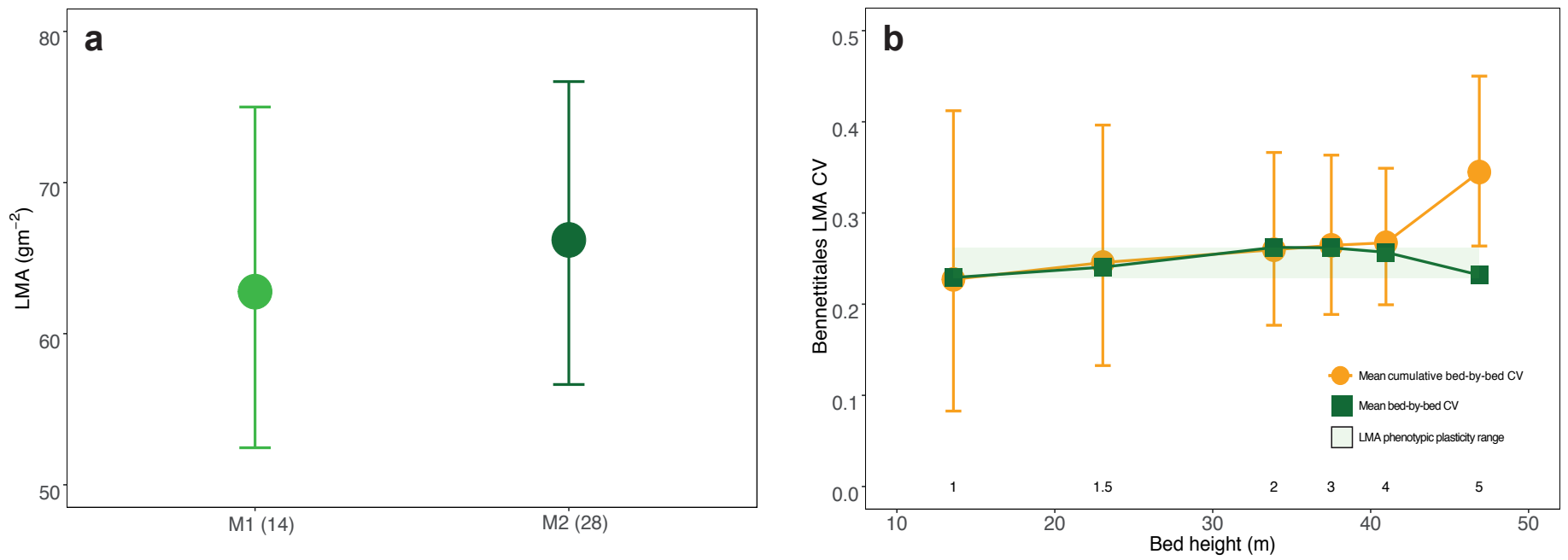

Fig. S10. Outer- and inner-canopy leaf mass per area (LMA) variation in Bennettitales. a, Dotplots of Bennettitales M1 ('sun') and M2 ('shade') leaf morphotype LMA (probability, $P($ M1 LMA $>$ M2 LMA) $=0.25$ ). Dotplots showing Bennettitales leaf mass per area (LMA) coefficient of variation (CV) and cumulative LMA CV plotted against Astartekløft Plant Beds (Beds 1-5, numbered inside figure). From Beds 1-4, Bennettitales cumulative bed-by-bed LMA CV values are within or nearly similar in value with bed-by-bed LMA CV. At Bed 5, cumulative LMA CV is outside LMA-phenotypic range and is likely to be higher than all other cumulative LMA CVs (probability, $P=0.93$ ). Whiskers are 95\% prediction interval. 


\section{Supplementary Information References}

1 Reich, P. B., Walters, M. B. \& Ellsworth, D. S. From tropics to tundra: Global convergence in plant functioning. Proceedings of the National Academy of Sciences 94, 13730-13734 (1997).

2 Wright, I. J. \& Westoby, M. Leaves at low versus high rainfall: coordination of structure, lifespan and physiology. New Phytologist 155, 403-416 (2002).

3 Wright, I. J. \& Westoby, M. Nutrient concentration, resorption and lifespan: leaf traits of Australian sclerophyll species. Functional Ecology 17, 10-19, doi:10.2307/3599023 (2003).

4 Royer, D. L. et al. Fossil leaf economics quantified: calibration, Eocene case study, and implications. Paleobiology 33, 574-589 (2007).

5 Haworth, M. \& Raschi, A. An assessment of the use of epidermal micro-morphological features to estimate leaf economics of Late Triassic - Early Jurassic fossil Ginkgoales. Review of Palaeobotany and Palynology, doi:doi: 10.1016/j.revpalbo.2014.02.007 (2014).

6 Onoda, Y., Richards, L. \& Westoby, M. The importance of leaf cuticle for carbon economy and mechanical strength. New Phytologist 196, 441-447, doi:10.1111/j.1469-8137.2012.04263.x (2012).

7 VILE, D. et al. Specific Leaf Area and Dry Matter Content Estimate Thickness in Laminar Leaves. Annals of Botany 96, 1129-1136, doi:10.1093/aob/mci264 (2005).

8 Felsenstein, J. Phylogenies and the Comparative Method. The American Naturalist 125, 1-15 (1985).

9 Webb, C. O. \& Donoghue, M. J. Phylomatic: tree assembly for applied phylogenetics. Molecular Ecology Notes 5, 181-183, doi:10.1111/j.1471-8286.2004.00829.x (2005).

10 The Angiosperm Phylogeny, G. An update of the Angiosperm Phylogeny Group classification for the orders and families of flowering plants: APG III. Botanical Journal of the Linnean Society 161, 105-121, doi:10.1111/j.1095-8339.2009.00996.x (2009).

11 Lu, Y., Ran, J.-H., Guo, D.-M., Yang, Z.-Y. \& Wang, X.-Q. Phylogeny and Divergence Times of Gymnosperms Inferred from SingleCopy Nuclear Genes. PLoS ONE 9, e107679, doi:10.1371/journal. pone.0107679 (2014).

12 Webb, C. O., Ackerly, D. D. \& Kembel, S. W. Phylocom: software for the analysis of phylogenetic community structure and trait evolution. Bioinformatics 24, 2098-2100, doi:10.1093/ bioinformatics/btn358 (2008).

13 Evert, R. F. in Esau's Plant Anatomy 211-253 (John Wiley \& Sons, Inc., 2006).

14 Doube, M. et al. BoneJ: Free and extensible bone image analysis in ImageJ. Bone 47, 1076-1079, doi:10.1016/j.bone.2010.08.023.

15 Royer, D. L., Miller, I. M., Peppe, D. J. \& Hickey, L. J. Leaf economic traits from fossils support a weedy habit for early angiosperms. American Journal of Botany 97, 438-445, doi:10.3732/ ajb.0900290 (2010).

16 Blonder, B. et al. The leaf-area shrinkage effect can bias paleoclimate and ecology research. American Journal of Botany 99, 1756-1763, doi:10.3732/ajb.1200062 (2012).
17 Poorter, H., Niinemets, U., Poorter, L., Wright, I. J. \& Villar, R. Causes and consequences of variation in leaf mass per area (LMA): a meta-analysis. New Phytologist 182, 565-588, doi:10.1111/j.1469-8137.2009.02830.x (2009).

18 Shipley, B. Structured interspecific determinants of specific leaf area in 34 species of herbaceous angiosperms. Functional ecology. 9, 312-319 (1995).

19 Spicer, R. A. The Formation and Interpretation of Plant Fossil Assemblages. Advances in Botanical Research Incorporating Advances in Plant Pathology 16, 95-191 (1989).

20 Sack, L., Melcher, P. J., Liu, W. H., Middleton, E. \& Pardee, T. How strong is intracanopy leaf plasticity in temperate deciduous trees? American Journal of Botany 93, 829-839 (2006).

21 Steinthorsdottir, M., Bacon, K. L., Popa, M. E., Bochner, L. \& McElwain, J. C. Bennettitalean leaf cuticle fragments (here Anomozamites and Pterophyllum) can be used interchangeably in stomatal frequency-based palaeo- $\mathrm{CO}_{2}$ reconstructions. Palaeontology 54, 867-882, doi:10.1111/j.14754983.2011.01060.x (2011).

22 Huynh, T. \& Poulsen, C. Rising atmospheric $\mathrm{CO}_{2}$ as a possible trigger for the end-Triassic mass extinction. Palaeogeography, Palaeoclimatology, Palaeoecology 217, 223-242 (2005).

23 Hesselbo, S. P., Robinson, S. A., Surlyk, F. \& Piasecki, S. Terrestrial and marine extinction at the Triassic-Jurassic boundary synchronized with major carbon-cycle perturbation: A link to initiation of massive volcanism? Geology 30, 251-254 (2002).

24 McElwain, J. C., Popa, M. E., Hesselbo, S. P., Haworth, D. M. \& Surlyk, F. Macroecological responses of terrestrial vegetation to climatic and atmospheric change across the Triassic/Jurassic boundary in East Greenland. Paleobiology 33, 547-573 (2007).

25 Mander, L., Kürschner, W. M. \& McElwain, J. Palynostratigraphy and vegetation history of the Triassic-Jurassic transition in East Greenland. Journal of the Geological Society 170, 37-46 (2013).

26 Steinthorsdottir, M., Jeram, A. J. \& McElwain, J. C. Extremely elevated $\mathrm{CO}_{2}$ concentrations at the Triassic/Jurassic boundary. Palaeogeography, Palaeoclimatology, Palaeoecology 308, 418432, doi:http://dx.doi.org/10.1016/j.palaeo.2011.05.050 (2011).

27 Bacon, K. L., Haworth, M., Conroy, E. \& McElwain, J. C. Can atmospheric composition influence plant fossil preservation potential via changes in leaf mass per area? A new hypothesis based on simulated palaeoatmosphere experiments. Palaeogeography, Palaeoclimatology, Palaeoecology, doi: http://dx.doi.org/10.1016/j.palaeo.2015.12.006.

28 Bacon, K. L. Tracking and interpreting leaf physiognomy and stable carbon isotopic composition across the Triassic-Jurassic boundary Ph.D. thesis, University College Dublin, (2012). 